\author{
A. Serkov ${ }^{1}$, P. Pustovoitov ${ }^{1}$, I. Yakovenko ${ }^{1}$, B. Lazurenko ${ }^{1}$, G. Churyumov ${ }^{2}$, V. Tokariev ${ }^{2}$, W. Nannan ${ }^{3}$ \\ ${ }^{1}$ National Technical University "Kharkiv Polytechnic Institute", Kharkiv, Ukraine \\ ${ }^{2}$ Kharkiv National University of Radio Electronics, Kharkiv, Ukraine \\ ${ }^{3}$ Harbin Institute of Technology, Harbin, China
}

\title{
ULTRA WIDEBAND TECHNOLOGIES IN MOBILE OBJECT MANAGEMENT SYSTEMS
}

\begin{abstract}
The subject of study is the processes of noise immunity ensuring of wireless control channels and mobile objects communication. The aim of article is to increase the capacity and noise immunity of control and communication systems under the natural and intentional interference influence. The concept is based on the technology of ultra-wideband communication that consists in the transmission of low-power coded pulses in a very wide bandwidth without a carrier wave. The task is to ensure stable and safe operation of mobile objects. Methods used: methods of analytical, simulation, and temporal position-pulse coding. The following results were obtained. A security concept has been developed for wireless control channels and mobile objects communication. It is shown that in order to obtain high noise immunity of control and communication channels and to protect information from interception, it is necessary to apply wireless ultrawideband communication technology, which allows providing of large capacity and transmission rate. The possibility of joint interference-free operation in the same frequency range of both traditional narrow-band communication systems and systems using ultra-wideband signals is grounded. A technical solution for the design of an ultra-wideband receivingtransmitting antenna system is proposed. Conclusion. The usage of channels with an ultra-wide bandwidth allows an almost unlimited increase in the number of control and communication channels of mobile objects. Pre-distribution between the channels of orthogonal codes implements the process of control and communication without interception of information and mutual interference. Moreover, the usage of the temporal position-pulse coding method prevents intersymbol distortions of coding ultrashort pulses. It also reduces the rate of information signals distortion caused by its multipath propagation that guarantees the safety of managing mobile objects.
\end{abstract}

Keywords : control system; mobile object; noise immunity; line capacity.

\section{Introduction}

Unmanned aerial vehicles (UAV) utilize critical systems in which incorrectly received information by the control system can lead to a catastrophe. In addition, reliability demands of these systems constantly increasing. In the same time analysis of failures of such systems showed that the number of accidents and the associated risks has a strong tendency to increase. The most dangerous are emergencies caused by information distortions in control channels that are caused by external influencing factors. Qualification norms and onboard durability standards of aviation equipment to the effects of external affecting factors are detailed in standard [1].

Analysis of the requirements set out in standard has shown that are particularly dangerous cases where, as a source of external impact is a powerful electromagnetic field, accompanying lightning discharge [2-4]. Wide frequency range $(0.3-30 \mathrm{MHz})$ in combination with large amplitude pulsed electromagnetic fields $(15-100 \mathrm{kV} / \mathrm{m})$ are the most dangerous reliability factors of an aircraft. In this way, noise immunity, reliability and quality of received data plays a pivotal role in drones control channels.

\section{The analysis of problem and formulation of the task}

Noise resistance of control channel means maximum level of electromagnetic interference affecting the control channel at which it saves the required quality of work [5]. In order to increase noise immunity we should encode information in the information channels and management channels. In the presence of external impact factors, block codes that are able to correct mistakes have an advantage over binary codes. However, these codes require double redundancy, which leads to reduced speed of information transfer. At the same time, in order to increase the transmission rate control signals in wireless channels requires using the widest possible frequency range. Among all onboard systems of aircraft the most widespread protocol MIL-STD-1553B (Ministry of Defense USA), application which is due to a fairly high level noise immunity of systems. Protocol provides maximum data transfer rate of $1 \mathrm{Mbps}$ with a spectral efficiency of $1 \mathrm{bit} / \mathrm{Hz}$. This way, the transmission duration of one bit coded information is $1 \mu \mathrm{s}$. [6, 7]. It should be noted that a high level of protocol noise immunity is provided by availability of additional communication channels. Other UAV control channels serve as a reserve in case of failure of the main channel. However, the time needed to switch from the main channel transfer to secondary one eliminates the possibility of effectively increasing the noise immunity by using additional control and communication channels. Thus, known methods of encoding information in wireless flight control channels devices do not provide the necessary level of noise immunity. This situation requires the development of new.

\section{Task solution}

In wireless control and communication channels, transmission medium is a physical path between transmitter and receiver. The quality of information transfer is defined by environmental characteristics and signal characteristics. Major factor imposing restrictions on transmission, is the environment itself. The main 
source of losses in communication systems, like any other systems is the attenuation $L$, which is determined by the ratio:

$$
L=10 \lg (4 \pi d / \lambda)^{2} \text { дБ, }
$$

where $d$-distance, $\mathrm{m} ; \lambda$ - wavelength, $\mathrm{m}$.

So, with the middle frequency band [8] of the satellite mobile of $6 \mathrm{GHz}$, transmitter power signal of 10-30 W and the length of the radio lines $4 * 10^{4} \mathrm{~km}$., the attenuation coefficient of free space on the radio line is $10^{20}$. At the same time, the average value of the power of information signals at the input receiver is $10^{-14} \mathrm{~W}$, that provides stability of operation of the communication channel.

However, when we determine characteristics of information transfer, the medium itself is not the most important factor, but the bandwidth of the emitted signal. The most common and optimal range for wireless control and communication systems is from 1 to $10 \mathrm{GHz}$. [9]. This is due to the fact that at frequencies below $1 \mathrm{GHz}$ there are significant atmospheric interference and interference from various electronic devices. At the same time, at frequencies above $10 \mathrm{GHz}$, signal absorption by the atmosphere and precipitation is large. Thus, the frequency range from 1 to $10 \mathrm{GHz}$ is the most suitable for organizing a control channel for unmanned aerial vehicles. At the same time, the need to organize highspeed wireless control and communication channels requires an increase in the width of the frequency range of the control channel. On the other hand, there is a physical limitation of the frequency spectrum. Therefore, the development of technologies of ultra-wideband communications that resolve this contradiction is relevant.

The aim of the work is to increase the bandwidth and noise immunity of control and communication systems under the action of natural and deliberate interference.

The achievement of this goal became possible by using ultra-wideband signals (UWBS), in particular: ultrashort pulses with durations of the order of units and fractions of a nanosecond [10,11].

By definition, L.Yu. Astanin [12] UWBS are signals whose spectral width commensurate with the center frequency.

When using broadband transmission, a deliberate conversion of relatively narrow-band information signals with an efficiently transmitted spectrum width $\Delta f$ into a broadband signal with an efficiently transmitted spectrum width $\Delta F$ while maintaining the total signal energy $E$ is carried out. In this case, the spectral density of the energy of the channel signal is deliberately reduced in $\Delta F / \Delta t$ times, which will be $\Delta E / \Delta F$, and the base of the channel signal will increase by a factor of $\Delta F / \Delta f$.

The basis of the ultrashort pulse UWBS is the product of the signal duration and the width of its spectrum:

$$
\mathrm{B}=\Delta t \cdot \Delta F \approx 1,
$$

where $\Delta t-$ impulse duration, $\Delta F-$ pulse power spectrum width.
Thus, direct spreading of the frequency spectrum is the simplest and most convenient method for expanding the base of a signal. Moreover, the higher the frequency used, the higher the potential data transfer rate. Thus, UWBS - technology is to transmit low-power coded pulses in a very wide frequency band without a carrier frequency. In this case, it is not a harmonic oscillation that is emitted, but an ultrashort pulse, the duration of which lies within $0.2-2.0 \mathrm{nS}$, and the period of the pulse sequence is $10-100 \mathrm{nS}$. Typically, such signals have the form of idealized Gaussian monocycles, the main part of the emission spectrum of which is in the frequency range from 1 to $10 \mathrm{GHz}$ [9]. So use as a coding pulse monocycle Gauss duration of $2.0 \mathrm{nS}$. up to $0.1 \mathrm{nS}$, the power spectrum bandwidth will be respectively from $500 \mathrm{MHz}$ to $10 \mathrm{GHz}$. And the spectrum of the signal will occupy the entire frequency band from 0 to $\Delta F \approx 1 / \Delta t$. For the practical implementation of UWBS, powerful impulse keys with a switching front duration of the order of $10-100 \mathrm{pS}$ are needed megahertz repetition rate and high stability of the order of $10 \mathrm{pS}$. As high-speed switches, drift diodes should be used with a sharp recovery of the locking properties [13, 14]. The family of electric impulse generators created on this basis makes it possible to practically implement UWBS technology. In the UAV control channel, information is encoded by means of temporal positionpulse modulation [6]. So the pulse offset relative to the reference position in the sequence forwards sets the zero bit, and backward - sets one. The offset time does not exceed a quarter of the pulse duration, and one information bit is encoded by a sequence of many pulses per bit. To separate information communication channels, the position of each pulse is shifted by a time proportional to the current value of a certain pseudorandom sequence. Moreover, the shift time is one to two orders of magnitude higher than the shift during time modulation. Each channel is assigned its own spreading code combination, the elements of which constitute the orthogonal basis and specify the channel code. In addition the decoding of the information message is carried out only if the receiver and transmitter use the same channel code, which increases the noise immunity of signals in the wireless control and communication system of the UAV. The separation of the useful signal in the background noise is carried out by the correlation of the received and reference signals. The correlator performs a convolution of the received signal from the reference one. It is an ideal detector for determining the time shifts of received pulses relative to the reference. So when receiving a unit, the correlation function is +1 , and when receiving 0 , it takes the value -1 . In all other cases, the correlation function is 0 . And since the information bit is represented, for example, by 200 ultrashort pulses, then if the code coincides, they accumulate in the integrator receiver and the bit will be detected correctly, even if 99 pulses out of 200 will be spoiled. The useful signal stands out from the noise level, significantly exceeding its signal-to-noise ratio. In this case, the coding of the information bit by a series of ultrashort pulses eliminates the problem of multipath propagation of the signal, since the signal arriving with 
a shift in time due to different paths will be rejected as interfering. At the same time, the use of a series of ultrashort pulses to encode the information bit makes it possible to eliminate intersymbol interference. This is due to the fact that before the passage of the next ultrashort pulse from the coding series, the energy of the previous pulse has time to completely dissipate.

In wireless UAV control channels, the key issue is the reception and transmission of UWBS. Due to the fact that coded impulse signals are to be transmitted in a very wide frequency band without a carrier frequency, the requirements for broadband receiving and transmitting antennas are specific. The technical characteristics of the most acceptable is the antenna element [15], which is an antenna with an expanding slot (Tapered Slot Antenna - TSA).

The shape of the open slit determines the frequency band, and the energy pattern of the antenna is characterized by a narrow main beam and almost no side lobes. The antenna has a complex surface shape, therefore, to study the characteristics of such an antenna, a software package for three-dimensional electrodynamic modeling HFSS was used. A model was created in this package (Fig. 1) [16].

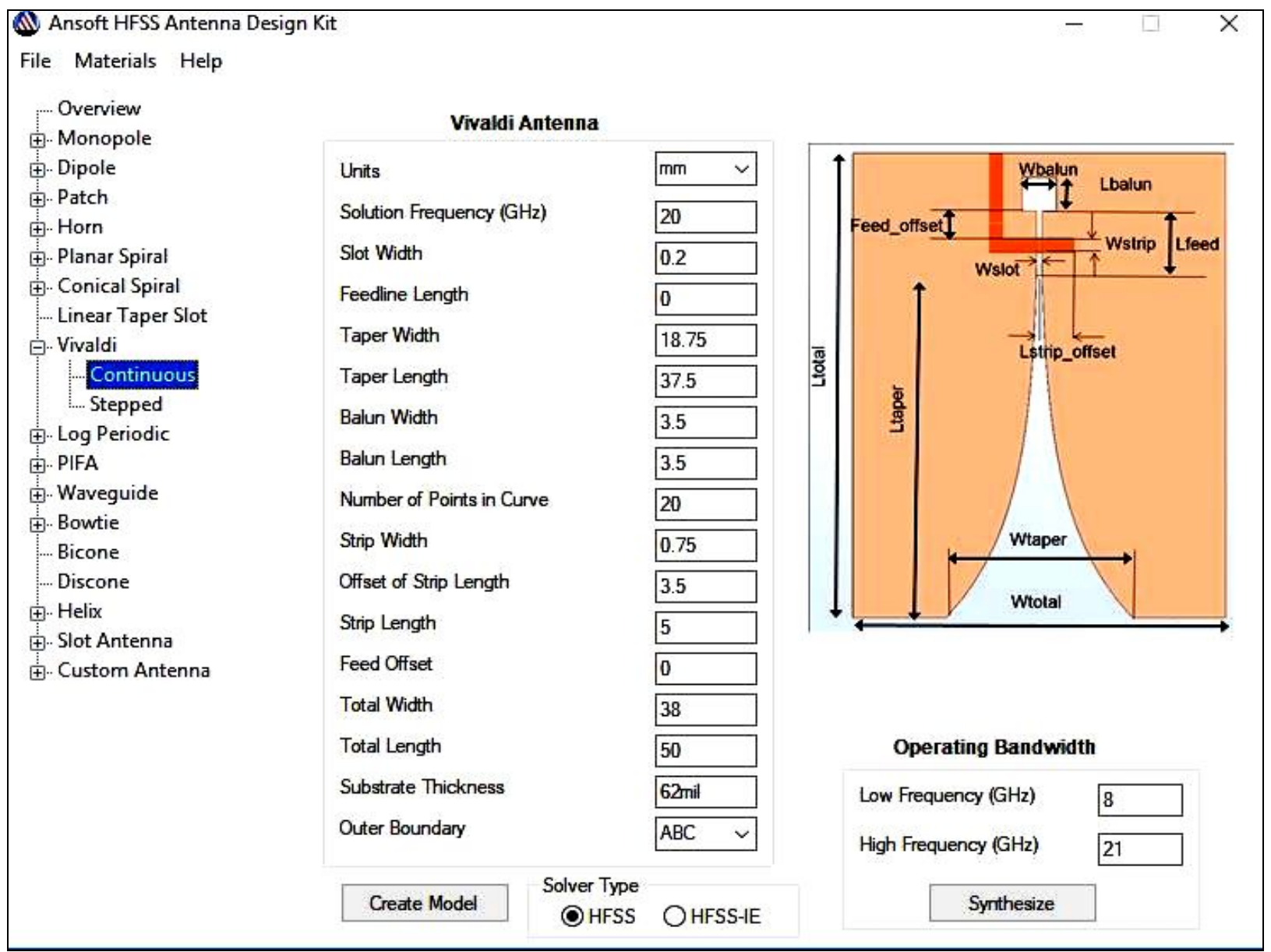

Fig. 1. TSA - antenna model

The simulation results (Fig. 2) showed sufficient antenna bandwidth, which showed the feasibility of using it in ultra-wideband technologies.

However, the preliminary formation of an UWBS (Gaussian monocycle) that is sent to the antenna system causes coordination difficulties in a wide frequency range. This is observable in the form of the reflections of individual components of UWBS, which distort the shape of the Gaussian monocycle.

To eliminate these drawbacks, a model (Fig. 3) of a TSA binary antenna $[17,18]$ has been proposed. In the proposed technical solution, the informative mono-pulse signal is divided in half. One part of the signal is successively inverted and delayed by a time equal to a half of the duration of the single pulse. Then, using both monopoles signals, excite respectively two adjacent TSA antennas placed on a single dielectric base. The electromagnetic fields of two unipolar pulses - the main and inverted - interfere in the equivalent common space of the aperture of the antennas, creating the electromagnetic field of the bipolar pulse, which is an ultra-wideband pulse signal. This eliminates the time interval between the two parts of the radiated field, which is typical of a single-pulse TSA antenna. It should also be noted that the ultra-wideband pulsed antenna is capable of emitting both an ultrashort unipolar mono-pulse and a bipolar-pulsed information signal.

Moreover, the proposed technical solution allows to significantly increasing the range of propagation of pulsed electromagnetic signals. Thus, compared with the radiation level of a unipolar pulsed signal, the propagation distance of a bipolar pulse generated in the aperture of the antenna increases by 9.5 times, and compared to a monochromatic signal - by 2.37 times [15]. 


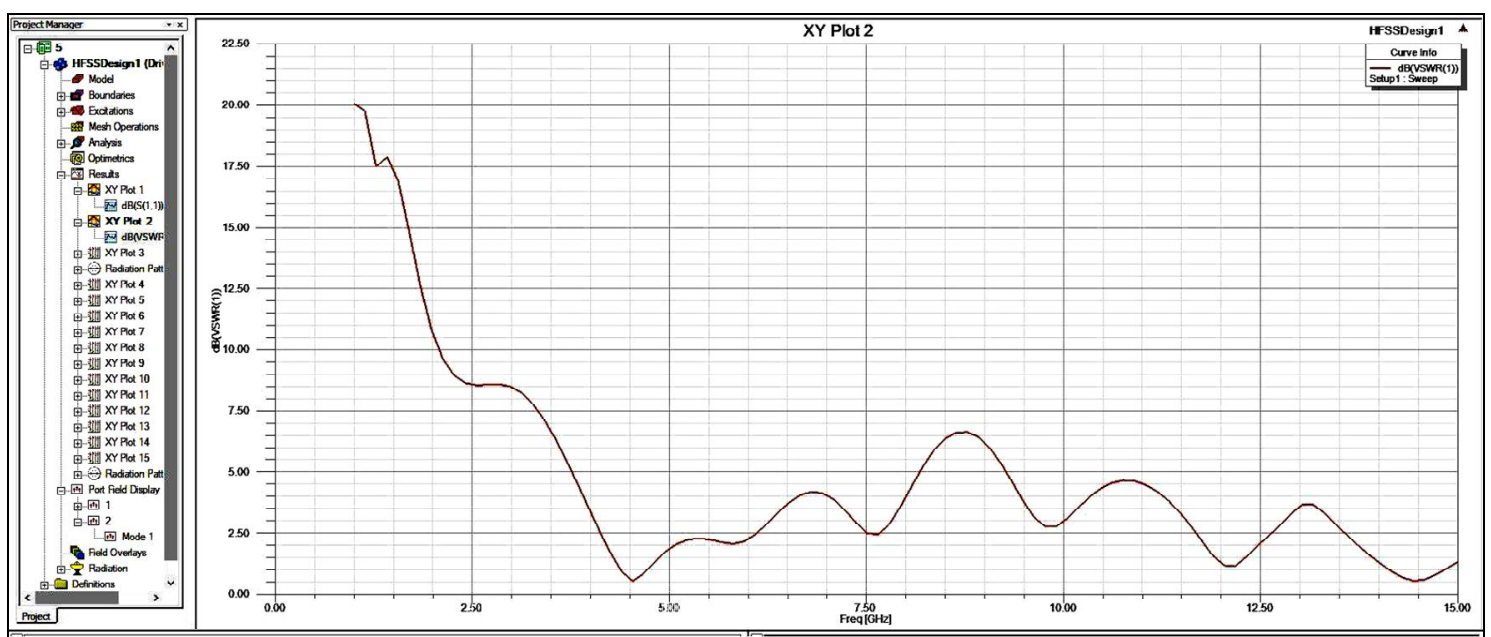

Fig. 2. Test results

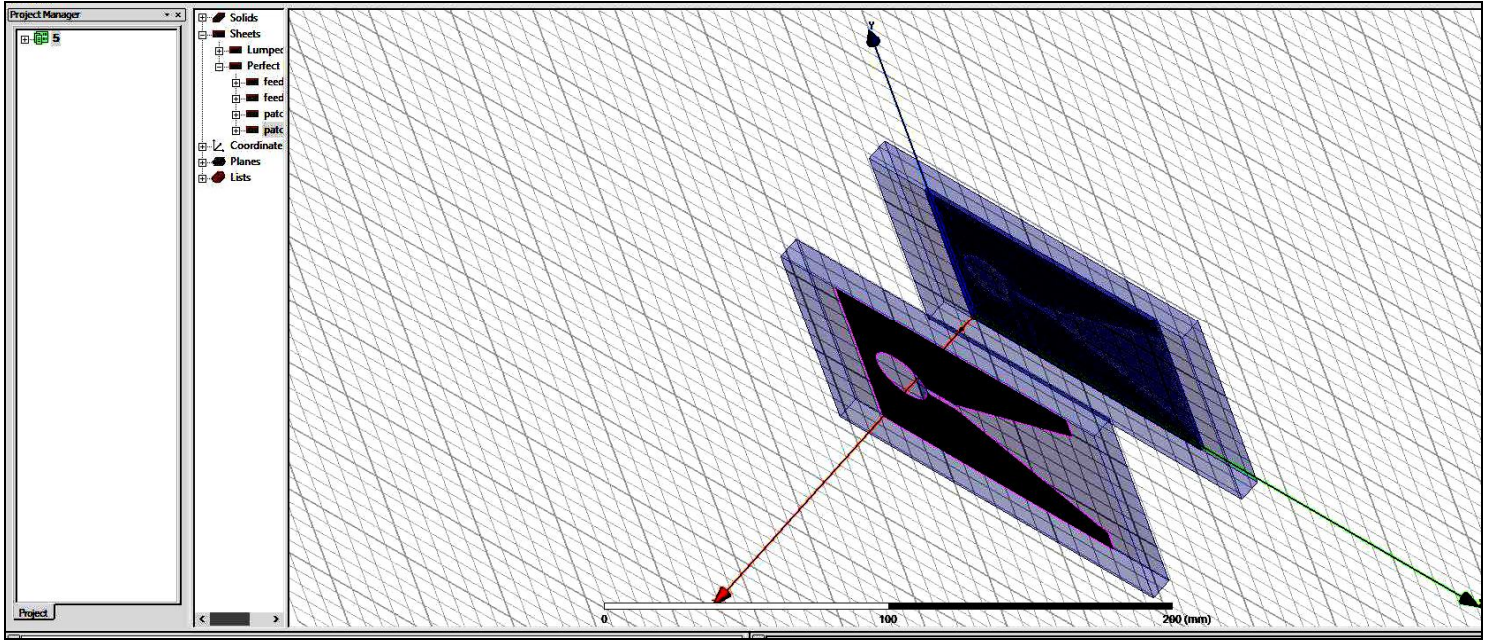

Fig. 3. Binary antenna TSA

\section{Conclusions}

The use of UWBS technology in the control and communication channels of the UAV allows obtaining a number of advantages that cannot be achieved by traditional methods. In particular, this relates to improving the quality indicators of the UAV control channels. The expansion of the communication channel bandwidth and the transition to channels with an ultrawide bandwidth allows for an almost unlimited increase in the number of communication channels. By distributing modulation codes between UAVs in advance, their control is implemented without interception of control and mutual interference.

The most important criterion characterizing the effectiveness of wireless communication systems is the high potential specific data transfer density. It is defined as the value of the achievable total data transfer rate per square meter of the working area and has today the value of this indicator - about $1 \mathrm{Mbit} / \mathrm{s}$.

The use of short pulses prevents intersymbolic distortions since the energy of the received pulse practically always has time to almost completely fade before the next pulse arrives. It also reduces the level of distortion of information signals caused by its multipath propagation.
A characteristic feature inherent in control and communication systems based on UWBS is the low probability of detecting both the fact of the temporary establishment of a communication channel and the impossibility of intercepting a unmanned aerial vehicles control channel.

Simultaneous noise-free operation in the same frequency range of both traditional narrow-band communication systems and UWBS systems is due to the fact that the level of the control signal does not exceed the noise level in the working frequency range.

At the same time, a reduction in the power and radiation level of electromagnetic fields makes it possible to ensure that the requirements of electromagnetic compatibility are met at all stages of the development and implementation of UAV control and communication systems.

\section{Acknowledgment}

The authors express personal gratitude for the continued assistance and financial support to the group EMC of Research \& Design Institute "Molniya", EMC Certificate Test Center "Impuls". Especially colleague Prof. Kravchenko V. I., Sen. Res. Knyazev V. V., Nemchenko Yu. S., Lesnoy I. P. 
REFERENCES

1. Qualifying Requirements QR-160D (2004), Environmental Conditions and Test Procedures for Airborne Equipment, ARIAC.

2. International Standard IEC 62305-1 Edition 2.0 2010-12 (2010), Annex A. Parameters of lightning current. Annex B. Time functions of the lightning current for analysis purposes.

3. Ruban I.V., Churyumov, G.I., Tokarev, V.V. and Tkachov, V.M. (2017), "Provision of Survivability of Reconfigurable Mobile System on Exposure to High-Power Electromagnetic Radiation", Selected Papers of the XVII International Scientific and Practical Conference on Information Technologies and Security (ITS 2017), CEUR Workshop Processing, Kyiv, Ukraine, November 30, pp. 105-111.

4. Churyumov, G., Tokariev, V., Tkachov, V. and Partyka, S. (2018), "Scenario of Interaction of the Mobile Technical Objects in the Process of Transmission of Data Streams in Conditions of Impacting the Powerful Electromagnetic Field", 2018 IEEE Second International Conference on Data Stream Mining \& Processing (DSMP), 21-25 Aug. 2018, pp. 183-186.

5. International Standard IEC 1000-4-92 (1992), Immunity tests. Resistant to interference, Level of noise immunity.

6. Serkov, A., Breslavets, V., Tolkachov, M. and Kravets, V. (2018), "Method of coding information distributed by wireless communication lines under conditions of interference", Advanced Information Systems, Vol. 2, No.2, pp. 145-148, DOI: https://doi.org/10.20998/2522-9052.2018.2.25

7. Serkov, A., Kravets, V., Sokolov, S., Breslavets, V., Shevtsova, V., Tolkachev, M., Marchenko, D. and Lazurenko, B. (2018), "Computer modeling of the process of stress and current generation in cable communication lines as a result of electromagnetic field, accompanying lightning discharge", Research report under the contract No. 65708, December 222017 (2018), $57 \mathrm{p}$.

8. Makarenko, S.I. (2017), Informational confrontation and electronic warfare in the network-centric wars of the beginning of the XXI century, High Technologies, St. Petersburg, 546 p.

9. Harmuth, H.F. (1981), Non sinusoidal Waves for Radar and Radio Communication, Academic Press, New York, London, Toronto, Sydney, San Francisco, 376 p.

10. Serkov, A., Breslavets, V., Tolkachov, M., Churyumov, G. and Issam, Saad (2017), "Noise-like signals in wireless information transmission systems", Advanced Information Systems, 2017, Vol. 1, No. 2, pp. 33-38, DOI: https://doi.org/10.20998/2522-9052.2017.2.06

11. Serkov, A.A. and Churyumov, G.I. (2017), "On the issue of solving the problem of electromagnetic compatibility of the wireless telecommunication systems", Applied radio electronics, Vol. 16, No. 3-4, pp. 117-121.

12. Varganov, M.E., Zinoviev, Yu.S. and Astanin, L.Yu. (1985), Radiocative Characteristics of Aircraft, Radio and Communication, Moscow, $236 \mathrm{p}$.

13. Kordo-Sysoev, A.F. and Prylevsky, V.L. (2000), "Powerful Sourced of Ultra wide Bond Pulsed Cogerent Signals", "EUROEM 2000" Euro Electromagnetic, Edinburg.

14. Serkov, A., Breslavets, V., Yakovenko, I. and Dziabenko, O. (2018), "Excitation of surface vibrations of semiconductor structures exposed to external electromagnetic radiation", Advanced Information Systems, Vol. 2, No. 3, pp. 142-146, DOI: https://doi.org/10.20998/2522-9052.2018.3.25

15. Serkov, O., Breslavets, V., Tolkachov, M. and Churyumov G. (2018), "The Wideband Pulsed Antenna and its Application", 9-th Inter. Conf. on Ultra wideband and Ultrashort Impulse Signals (UWBUSIS-2018), September 4-7, Odessa, Ukraine, ISBN: 978-1-5386-2467-8, IEEE Catalog Number: CFP18587, pp. 340-343.

16. Marusenko, N.N. (2018), Model and method for providing ultra-wideband wireless communications, NTU "KhPI", Kharkov, $103 \mathrm{p}$.

17. Serkov, O.A., Breslavets, V.S., Tolkachov, M.Yu. and Churyumov G.I. (2018), Method of Generation the Wideband Impulse Signals and Antenna for his Realization, Patent appl. of Ukraine, for utility model number a 2018 03104; appl. 26.03.2018.

18. Serkov, A. and Churyumov G. (2018), "Ultra Wideband Signals in Wireless Control Systems and Communication", 4-th China-Ukraine Science and Technology Forum, September 14-19, Harbin Institute of Technology, Harbin, China.

Received (Надійшла) 11.03.2019

Accepted for publication (Прийнята до друку) 15.05.2019

\section{ВідОМості ПРО АвтоРів / АвоUT тHE AUTHORS}

Серков Олександр Анатолійович - доктор технічних наук, професор, завідувач кафедри систем інформації, Національний технічний університет "Харківський політехнічний інститут”, Харків, Україна;

Aleksandr Serkov - Doctor of Technical Sciences, Professor, Head of Information Systems Department, National Technical University "Kharkiv Polytechnic Institute", Kharkiv, Ukraine;

e-mail: $\underline{\text { saa@kpi.kharkov.ua; ORCID ID: http://orcid.org/0000-0002-6446-5523 }}$

Пустовойтов Павло Євгенович - доктор технічних наук, доцент, професор кафедри систем інформації, Національний технічний університет "Харківський політехнічний інститут", Харків, Україна;

Pavel Pustovoitov - Doctor of Technical Sciences, Associate Professor, Professor of Information Systems Department, National Technical University "Kharkiv Polytechnic Institute", Kharkiv, Ukraine;

e-mail: p.pustovoitov@gmail.com; ORCID ID: http://orcid.org/0000-0003-3884-0200

Яковенко Ігор Володимирович - доктор фізико-математичних наук, професор, професор кафедри систем інформації, Національний технічний університет "Харківський політехнічний інститут", Харків, Україна;

Igor Yakovenko - Doctor of Physics and Mathematics, Professor, Professor of Information Systems Department, National Technical University "Kharkiv Polytechnic Institute", Kharkiv, Ukraine;

e-mail: yakovenko60iv@ukr.net; ORCID ID: http://orcid.org/0000-0002-0963-4347 
Лазуренко Богдан Олександрович - магістрант кафедри систем інформації, Національний технічний університет "Харківський політехнічний інститут", Харків, Україна;

Bohdan Lazurenko - Master Student of Information Systems Department, National Technical University "Kharkiv Polytechnic Institute", Kharkiv, Ukraine;

e-mail: torroloco789@gmail.com; ORCID ID: http://orcid.org/0000-0002-3339-1402

Чурюмов Геннадій Іванович - доктор фізико-математичних наук, професор, професор кафедри фотоніки та лазерної інженерії, Харківський національний університет радіоелектроніки, Харків, Україна;

Gennady Churyumov - Doctor of Physics and Mathematics, Professor, Professor of Physical Foundations of Electronic Engineering Department, Kharkiv National University of Radio Electronics, Kharkiv, Ukraine;

e-mail: g.churyumov@ieee.org; ORCID ID: http://orcid.org/0000-0002-4826-510X

Токарєв Володимир Володимирович - кандидат технічних наук, доцент, доцент кафедри електронних обчислювальних машин, Харківський національний університет радіоелектроніки, Харків, Україна;

Volodymyr Tokariev - Candidate of Technical Sciences, Associate Professor, Associate Professor of Electronic Computers Department, Kharkiv National University of Radio Electronics, Kharkiv, Ukraine; e-mail: tokarev.v@ukr.net; ORCID ID: http://orcid.org/0000-0003-4854-7403

Ванг Наннан - кандидат технічних наук, доцент, доцент кафедри мікрохвильових пристроїв, Харбінський технологічний інститут, Харбін, Китай;

Wang Nannan - PhD (Technical Sciences), Associate Professor, Associate Professor of Microwave Engineering Department, Harbin Institute of Technology, Harbin, China; e-mail: wangnn@hit.edu.cn; ORCID ID: http://orcid.org/0000-0002-4231-9330

\section{Надширокосмугові технології в системах управління мобільними об'єктами}

О. А. Серков, П. Є. Пустовойтов, І. В. Яковенко, Б. О. Лазуренко, Г. І. Чурюмов, В. В. Токарєв, Ванг Наннан

Анотація. Предметом вивчення $є$ процеси забезпечення завадостійкості безпроводових каналів управління та зв'язку мобільних об'єктів. Мета - підвищення пропускної здатності та завадостійкості систем управління та зв'язку в умовах дії природних та штучних завад. В основу концепції покладено технологію надширокосмугового зв'язку, суть якої полягає в передачі малопотужних кодованих імпульсів в дуже широкій смузі частот без несучої частоти. Задача забезпечення усталеної та безпечної роботи мобільних об’ єктів. Використані методи: методи аналітичного, імітаційного моделювання та часового позиційно-імпульсного кодування. Отримані наступні результати. Розроблена концепція забезпечення безпеки в безпроводових каналах управління та зв'язку мобільних об'єктів. Показано, що для отримання високої завадостійкості каналів управління і зв'язку та захисту інформації від перехоплення слід застосовувати технологію безпроводового надширокосмугового зв'язку, яка дозволяє забезпечити великі обсяги та швидкості передачі інформації. Обгрунтовано можливість сумісної беззавадової роботи в одному частотному діапазоні як традиційних вузькосмугових систем зв'язку, так і систем, які використовують над широкосмугові сигнали. Запропоновано технічне рішення щодо конструкції надширокосмугової приймально-передавальної антенної системи. Висновки. Використання каналів із надширокою смугою частот дає можливість практично необмеженого збільшення кількості каналів управління та зв'язку мобільних об'єктів. Попередній розподіл між каналами ортогональних кодів реалізує процес управління та зв'язку без перехоплення інформації та взаємних завад. Причому, використання методу часового позиційно-імпульсного кодування запобігає виникненню міжсимвольних спотворень кодуючих надкоротких імпульсів. При цьому також знижується рівень спотворень інформаційних сигналів, які викликані його багатопроменевим розповсюдженням, що гарантує безпеку управління мобільними об'єктами.

Ключ чо і сл ов а: система управління; мобільний об'єкт; завадостійкість; пропускна здатність.

\section{Сверхширокополосные технологии в системах управления мобильными объектами}

А. А. Серков, П. Е. Пустовойтов, И. В. Яковенко, Б. А. Лазуренко, Г. И. Чурюмов, В. В. Токарев, Ванг Наннан

Ан н от а ц я. Предметом изучения являются процессы обеспечения помехоустойчивости беспроводных каналах управления и связи мобильных объектов. Цель - повышение пропускной способности и помехоустойчивости систем управления и связи при действии естественных и преднамеренных помех. В основу концепции положена технология сверхширокополосной связи, которая заключается в передаче маломощных кодированных импульсов в очень широкой полосе частот без несущей частоты. Задача - обеспечение устойчивой и безопасной работы мобильных объектов. Используемые методы: методы аналитического, имитационного моделирования и временного позиционно-импульсного кодирования. Получены следующие результаты. Разработана концепция обеспечения безопасности в беспроводных каналах управления и связи мобильных объектов. Показано, что для получения высокой помехоустойчивости каналов управления и связи и защиты информации от перехвата следует применять технологию беспроводной сверхширокополосной связи, которая позволяет обеспечить большие объемы и скорости передачи информации. Обоснована возможность совместной безпомеховой работы в одном частотном диапазоне как традиционных узкополосных систем связи, так и систем, использующих сверхширокополосные сигналы. Предложено техническое решение по конструкции сверхширокополосной приемо-передающей антенной системы. Выводы. Использование каналов со сверхширокой полосой частот дает возможность практически неограниченного увеличения числа каналов управления и связи мобильных объектов. Предварительное распределение между каналами ортогональных кодов реализует процесс управления и связи без перехвата информации и взаимных помех. Причем, применение метода временного позиционно-импульсного кодирования предотвращает межсимвольные искажения кодирующих сверхкоротких импульсов. При этом также снижается уровень искажений информационных сигналов, вызванных его многолучевым распространением, что гарантирует безопасность управления мобильными объектами.

Ключевые слов а: система управления; мобильный объект; помехоустойчивость; пропускная способность. 